\title{
Eating Behaviors: Does Culture Play a Role in Our Food and Beverage Choices?
}

\author{
Aisha Ansari* \\ Capella University, Minnesota, USA \\ *Corresponding Author: Aisha Ansari, Capella University, Minnesota, USA
}

Received: July 20, 2020

Published: March 22, 2021

(C) All rights are reserved by Aisha Ansari.

\begin{abstract}
Choice in beverages, diet and health may all depend on our culture and ethnicity. Nutritional values found in fruit juice and carbonated beverages are often selected based on cultural norms. Exploring the nutritional benefits found in both fruit juices and carbonated drinks reveal health benefits and defenses against cancer and other chronic diseases. With a literary review in nutrition and beverage, and a philosophical grounded theory, an argument will be made in favor of the nutritional value found in fruit juices, water, coffee, tea, water and carbonated drinks, require a balance in beverage intake and food consumption. Codependency on both beverages and foods are necessary for optimum nutritional health.
\end{abstract}

Keywords: Beverages; Culture and Ethnicity; Fruit Juices

\section{Introduction}

When examining and exploring the nutritional benefits of drinking liquids in our diets, a debate with ongoing curiosity in its mysteries as found in the Holy Qur'an, Surat ul Maryam, 19:26. Maryam was instructed to eat and drink, historians and translators translate God's instructions as "kuli wa ishrabi", 19:26. Historians and translators also argue that these instructions from God are perceived as meaning to consume, drink, absorb, and eat. Supporting the concept of drinking liquids while eating, suggest that better digestion occurs when food and beverage are consumed together. Researchers at BMC Nutrition offer that during the day, and at specific times of the day, how and what we chose to eat, and drink determines our health. Nutritional benefits are embedded in our behaviors, which are derived from our cultural and ethnic backgrounds and environments. Nutritional values found in orange and apple juices differ. However, both juices offer sustained health and nutritional benefits which combat chronic illnesses and disease. Political environments often determine access to our food supply. Despite nutrition and food preferences, restrictions in labeling, food imports and exports, global awareness in staying healthy show improved pro- activity.
Soft drinks, milk, and water are also beverages which offer benefits in nutrition. Apples work with the intestinal tract and contributes to good bacteria needed for gastro-intestinal health. Carbonated beverages are credited to Gabriel Francois Venel. Carbonated beverages are beneficial in speeding up digestion and increasing the elimination of intestinal waste. Soft drinks are carbonated, and the carbon dioxide add a sparkling and bubbly taste, which increases appetite and consumption for food. Carbonated beverages are also a good source of hydration for the body. Despite the high demand for soft drinks and carbonated beverages, public health groups have issued a strong warning for consuming them at the cost of diabetes and obesity. Vartanian., et al. 2007 [1], reports that the controversy over carbonated beverages consumption is debatable and lacks substantial empirical evidence for a soft drink ban in public schools.

Pirouznia, found that in a mid-western American middle school attention to nutrition was more prominent in $7^{\text {th }}$ and $8^{\text {th }}$ graders, than when compared with sixth graders. Pirouznia also found that in American diet and food choices at the middle school level, Caucasians middle school children paid more attention to their diets, than other ethnic groups. Students were asked to respond to the 
Comprehensive Assessment of Nutrition, Knowledge, Attitudes and Practices (CANKAP) questionnaire. The data was recorded coded and analyzed in variance and frequencies using SAS and Pearson Coefficients. While all groups were aware of the benefits of fruits and vegetables in their diet, students from Caucasian background appeared more knowledgeable and presented better healthy eating behaviors. Pirouznia did not state whether the knowledge and eating behaviors were observed only at school with same menu choices are offered to all students, or if the questionnaire results were just from school day behaviors. Eating and social behaviors have long been associated with early life development.

When observing middle school scholars, $7^{\text {th }}$ and $8^{\text {th }}$ graders, I personally noticed that milk is consumed while at school and during the school year among all ethnic groups. This trend maybe the result of less exposure and availability while at school in sodas, juices, and other beverages containing sugar.

\section{Chronic illness and carbonated beverages}

The most associated illnesses from carbonated beverages are diabetes and weight gain. Vartanian., et al. [1] report that even with fruit juice content found in carbonated sugary beverages, nutritional benefits are non- detectable nor beneficial to our health. The Vartanian study which utilized longitudinal evidence, from diverse gender and age groups, also reported lower consumption in milk and calcium-based beverages (2007). Rogers reported that Americans individually consumed 50 gallons of carbonated beverages.

The Center for Disease Control and Prevention, CDC, reports that 1 in 5 youths, and 1 out of 4 young adults are being diagnosed with prediabetes, which may lead to type 2 diabetes (2019). Data for this study and conclusion were gathered based on the National Health and Nutrition Examination Survey during 2005 and 2016. CDC Director Robert E. Redfield, M.D. made a conclusive comment that lifestyle, early nutrition and eating behaviors are factors which contribute to the onset of type 2 diabetes.

Other key findings in this study include:

- Young males ages 12-18, living with prediabetes are higher than those of females from the same age group. This group was also found with confounders such as obesity.

- Hispanic youths and young adults showed higher incidences in prediabetes than their white counterparts.

- Youths and young adults with prediabetes have higher levels of cholesterol, systolic blood pressure, and lower sensitivity to insulin.
During 2011 and 2016, 12-year-old adolescents in Malaysia statistics in obesity increased from $6.1 \%$ to $11.9 \%$ [2]. Adolescents were observed in Terengganu, Malaysia to determine sociodemographic linked to diabetes and cardiovascular disease. Twentythree percent of adolescents were found with obesity rates higher in boys than girls. Determinants which contributed to this obesity rate were parental body mass index, BMI, household size, income, and wage-earning parents. Interventions including eating behaviors and cultural environment are the main focuses in improved obesity rates.

The World Health Organization, WHO, is working to safeguard the health and well-being and preserving their human rights also reports that adolescents in developing countries experience undernourishment and poverty. However, on the other end of this spectrum WHO has noticed overweight and obesity among the low, middle, and high-income and developed countries.

\section{Ingredients found in soft drinks and carbonated beverages}

Ingredients commonly found in soft drinks and carbonated beverages include a long list of both natural and chemically made substances. These ingredients are verified by all globally recognized organizations as being safe for human consumption. Ingredients from acacia to zinc gluconate are used to make our beverages attractive and tasty.

Vitamins such as Vitamins A,B1, B12, B2, B3, B5 B6, Vitamin C, Vitamin $\mathrm{D}$ and $\mathrm{E}$ protect our bones, teeth, skin, and hair. These vitamins also play large roles in synthesizing and metabolizing energy and promoting a strong and healthy nervous system for human health and stability. Vitamin C, also known as Ascorbic Acid, is associated with orange juice is responsible for protecting cells and the tissues for health skin. Peter Hartlaub, a MSNBC contributor reminds us that orange juice a good source of Vitamin $\mathrm{C}$, sustains healthy kidneys which detox our bodies and keep us healthy. Vitamin D, normally associated with the milk we drink, promotes healthy bones, and synthesizes calcium and fat molecules.

Distilled water is made through steam then cooled and collected. This process removes harmful materials and impurities for drinking and consumption of manufactured drinks. Date and fig pastes, made from figs and dates, combined with water are used in foods and beverages to add sweetness and flavor. Magnesium Lactate, Sulfate and Chloride are electrolytes and used in bottled water for taste and essential for energy and body metabolism. In many of our carbonated beverages, water is the primary ingredient followed by sugar and artificial flavors. Artificial flavors are used to 
provide just as the name states, flavor. They also provide aroma and are man-made and approved by the recognized authorities including the U.S. Food and Drug Administration

Extracts are produced from berries and other fruits which also add natural flavor to drinks and beverages. Some drinks produce in other countries contain Dragon Fruit Extract, Dutch Cocoa, Garcinia Cambogia Rind Extract, a tress native to Southeast Asia, Guarana Extract and see found in Brazil. With the U.S. Food and Drug Administration and other recognized governing bodies, the Fair Trade exist to protect consumers and maintains social and environmental accountability. Fair Trade certification require the ingredients be certified by the recognized authority and governing organization for safe consumption.

Ingredients found in beverages and which are normally associated with foods, include Turmeric and Vanilla Extract. Turmeric is yellow in color like the ginger plant. Vanilla Extract comes from the vanilla bean. When consuming beverages a review of the ingredients will help to make wise choices in maintaining your health and safety.

\section{Turmeric latte}

Our friend, Sawsan at Chef in Disguise, shares a wonderful beverage full of natural and healthy ingredients. Turmeric Milk, Golden Milk, is made from eight ingredients and uses a form of distilling and boiling of milk. Let us rehearse the ingredients:

- Milk, about a liter and can be dairy or non-diary

- Ginger, peeled and chopped, or about $1 \frac{1}{2}$ teaspoons of ginger powder

- 1 stick cinnamon, or 1 teaspoon of ground cinnamon

- 5 pods of cardamom

- $1 / 4$ teaspoon of black pepper

- 1 teaspoon ghee or coconut oil

- Honey/sweetener to taste.

The author also shares scientific merit and synthesizes the importance of using ghee and black pepper for bodily absorption of the active ingredients in this recipe. Golden Milk, Turmeric Latte, is also linked to promoting antifungal properties, lower blood sugar and pressure, improves memory, and helps to prevent some cancers.

\section{Water and the importance of early childhood consumption}

Naturally, water, often taken for granted in the Western world, is required for sustainable and healthy living. Water being natural and plentiful, meets challenges in consumption with safety precautions, cost of desalination and utility. Dating back as far as during the time of our noble prophet, Muhammad, PBUH, water should be the preferred drink. Water should also be taken in sips and not gulps (Book 27, Hadith 185-194).

Arthur, 2018 reports that bottled water is the number one beverage in the United States. Carbonated beverages and juices are seeing a steadily decline in sales and consumption. For the second year in a row bottled water has won the number one ranking according to the International Bottled Water Association (IBWA) and Beverage Marketing Association (BMA). Children are being observed in the 21 st century with preferences in sugary and carbonated drinks and fruit juices. The American Journal in Public Health reports that children and adolescents experience less obesity and dental caries when their environments ensure safe drinking water [3].

BioMed Central Journal, BMC, Nutrition offers whether water is consumed before, during or after meals, it plays an important role in digestion. BMC also recommends drinking water because of the non-calorie intake and does not increase liquid capacity in the stomach and acid reflux. Water was confirmed to be the best beverage choice with smooth digestion and with optimal hydration benefits.

\section{Cultural background and diets}

Culture and ethnicity are important factors which determine our food choices, preparation, and consumption. Although in recent years Egypt has experienced a decrease in tourism, juice bars and shops are popular. Elgebali reports that innovation and not cultural preferences are the new determinants in Egyptian food and beverages (2019).

India, in a recent BioSpectrum report estimated the prevalence of Vitamin D deficiency is about $70 \%$ to $90 \%$, with a phenomenon of not being detected during the winter months (2019). Diet was not the blame for this deficiency but was due to the lack of exposure to the sun. Lifestyles and modernization with more daylight hours being spent indoors were also factors in this finding. An environmental concern in this scenario is that require UVB rays to synthesize Vitamin D. Children were prescribed with micellized supplements to eliminate the Vitamin D sufficiency.

Nestle, producer of chocolate and diversified beverages, recently came under ethical scrutiny in India. Soni and Harnawale [4], present the Nestle S.A. case with noodles and hot water. Maggi, Nestle's packaged noodles was found to contain harmful lead and stirred concerns for safe consumption. Because multi-national 
companies must be transparent with ingredients and nutritional value, Nestle and its Maggi noodles faced numerous investigations, recalls, and economic decline.

Nestle and the Ottoman Empire partnership dates to the late $19^{\text {th }}$ century. Koese [5], offer that the strategy in marketing is linked to Turkey's preference in natural flavors, or culture. In 1870 Nestle developed an infant formula which was marketed and sold globally. By 1875 Turkey ranked fifteenth in milk formula sales.

At University California, UC Davis, researchers expand the old saying that 'an apple a day keeps the doctor away.' In 1999, UC Da- vis researcher found that apple juice is good in antioxidants, which are needed as our bodies age to fight disease and illnesses. This study also supported the claim that apple juice contains excellent natural vitamins not found in the prescription and pill forms. One glass of concentrated orange juice, according to UC Davis, contains 5 oranges. UC Davis researchers urge families to supplement their fast food and take-out meals with fruit juice containing antioxidants to fight off fatty build up and tissue damage.

Carbonated beverage production and consumption with health risks and nutriton

\begin{tabular}{|c|c|c|c|c|c|}
\hline Beverage & Caloric data & & $\begin{array}{c}\text { U.S. Rates in } \\
\text { consumption }\end{array}$ & U.S. Health risks & Nutrition and health value \\
\hline $\begin{array}{l}\text { Natural and } \\
\text { Bottled Water }\end{array}$ & Zero calories & $\begin{array}{l}42 \text { gallons } / \text { per } \\
\text { capita }\end{array}$ & & $\begin{array}{c}\text { Asymptomatic } \\
\text { water intoxication, low } \\
\text { sodium blood levels }\end{array}$ & $\begin{array}{c}\text { May reduce obesity, } \\
\text { Assist enzyme production in the } \\
\text { stomach }\end{array}$ \\
\hline Apple Juice & $\begin{array}{c}114 \text { (Single serving } \\
\text { size) }\end{array}$ & $\begin{array}{l}1.6 \text { gallons } / \text { per } \\
\text { person }\end{array}$ & & $\begin{array}{l}\text { Moderation in } \\
\text { consumption, fruit } \\
\text { concentration. }\end{array}$ & $\begin{array}{c}\text { Fiber/Good Bacteria } \\
\text { Prevents Cancer } \\
\text { Prevents Type } 2 \text { Diabetes } \\
\text { Polyphenols } \\
\text { Vitamin C, K }\end{array}$ \\
\hline Orange Juice & $\begin{array}{c}56 \text { (Single serving } \\
\text { size) }\end{array}$ & $\begin{array}{l}2.45 \text { gallons/per } \\
\text { capita }\end{array}$ & & $\begin{array}{c}\text { Moderation in } \\
\text { consumption, } \\
\text { fruit concentration } 5 \\
\text { oranges }=1 \text { juice glass }\end{array}$ & $\begin{array}{l}\text { Immune and detox qualities } \\
\qquad \text { Vitamin C }\end{array}$ \\
\hline $\begin{array}{l}\text { Carbonated } \\
\text { Drinks- SODAS }\end{array}$ & $41-144 / 8$ oz- $12 \mathrm{oz}$ & $\begin{array}{l}40 \text { gallons } / \text { per } \\
\text { capita }\end{array}$ & & Type 2 Diabetes & $\begin{array}{c}\text { Aids digestion and intestinal waste } \\
\text { elimination } \\
\text { Caffeine }\end{array}$ \\
\hline Coffee & $\begin{array}{l}2 \text { (Without cream } \\
\text { and sugar) }\end{array}$ & $\begin{array}{l}26.5 \text { million bags/ } \\
\text { per household } 5 \mathrm{yr} \text {. } \\
\text { period }\end{array}$ & & $\begin{array}{c}\text { May interfere with } \\
\text { prescribed medications }\end{array}$ & $\begin{array}{c}\text { Contains Caffeine } \\
\text { Prevents Alzheimer's } \\
\text { Parkinson Diseases }\end{array}$ \\
\hline Tea & 2 (Unsweet) & $\begin{array}{c}84 \text { billion } \\
\text { servings } / 2018\end{array}$ & & Avoid if anemic & $\begin{array}{c}\text { Reduces obesity, defense against } \\
\text { Alzheimer's } \\
\text { Contains polyphenols } \\
\text { Antioxidant } \\
\text { Contains Caffeine }\end{array}$ \\
\hline Milk & $146 / 8 \mathrm{oz}$ & $\begin{array}{l}5.7 \text { gallons/per } \\
\text { capita }\end{array}$ & & $\begin{array}{l}\text { Lactic intolerant, causing } \\
\text { bloating and gas }\end{array}$ & Calcium , vitamins $\mathrm{D}, \mathrm{B}_{2,} \mathrm{~B}_{12}$, \\
\hline
\end{tabular}

Table 1

\section{Benefits from drinking coffee and tea}

Both the coffee bean and tea leaf have historical importance in our dietary awareness and eating habits. Hewlett and Wadsworth, reported that when determining preferences in caffeine and decaffeinated beverages, often age and demographics were factors (2012). The Hewlett and Wadsworth 2012 study of 7, 979 respon- 
dents revealed that men consume more caffeine beverages than women 30-70 years of age.

Our exploration in ethnicity, culture and eating behaviors focusing on crucial development and life cycles; adolescents and youth do not have regular consumption in coffee and tea.

\section{A word forward}

More research is needed to analyze the importance of drinking before, during and after eating a meal. However, in this writing a look at the nutritional benefits of the most popular beverages including juice and water were discussed. For scientific merit, many answers were self-evident in health and history. Water being the first known beverage will continue to produce needed health benefits and be a preferred drink for consumption. An attempt has been made to underscore the importance of nutritionally sound ingredients when choosing beverages. The need to make a collaboration between digestion and drinking perhaps happens without thought but moving forward wise choices in beverages is being encouraged. An agreement that culture and ethnicity do play major roles in what and how we consumer beverages. Therefore, our health and benefits gained from beverages can be measured based on these variables. Reading the labels and proactively purchasing and drinking nutrition and health conscious beverages will go a long way in improving our overall and sustainable health [6-22].

\section{Bibliography}

1. Vartanian L R., et al. "Effects of soft drink consumption on nutrition and health: A systematic review and meta-analysis". American Journal of Public Health 97.4 (2007): 667-675.

2. Davilla MG., et al. "The impact of parents on obesity among school adolescents in Malaysia". American Journal of Public Health 108.2 (2018): 151.

3. Patel Anisha I., et al. "Encouraging consumption of water in school and childcare settings: Access, challenges, and strategies for improvement". American Journal of Public Health 101.8 (2011): 1370-1379.

4. Soni PK and Harnawale C K. "Ethical responsibility of multinational companies: what went wrong with maggi brand of nestle India?" Indian Journal of Commerce and Management Studies 6.3 (2015): 73-76.

5. Koese Y. "Nestlé in the ottoman empire: Global marketing with local flavor 1870-1927". Enterprise and Society 9.4 (2008): 724-761.
6. Antolak H., et al. "Antibacterial and antiadhesive activities of extracts from edible plants against soft drink spoilage by asaia spp". Journal of Food Protection 80.1 (2017): 25-34.

7. Argan M., et al. "Leisure aspects of turkish coffee consumption rituals: An exploratory qualitative study". International Journal of Health and Economic Development 1.1 (2018): 26-36.

8. Arthur R. Bottled water is America's favorite drink! Bottled water takes the number one spot in the US (2018).

9. Banerjee S and Chatterjee J. "Efficient extraction strategies of tea (camellia sinensis) biomolecules”. Journal of Food Science and Technology 52.6 (2015): 3158-3168.

10. Elgebali M. "Marketing innovation in service smes a study in the egyptian food and beverage industry". International Journal of Entrepreneurship 23.3 (2019): 1-12.

11. Heng Y., et al. "The competition of beverage products in current market: A composite demand analysis". Agricultural and Resource Economics Review 47.1 (2018): 118-131.

12. Hewlett $P$ and Wadsworth E. "Tea, coffee and associated lifestyle factors". British Food Journal 114.3 (2012): 1-10.

13. KUO L. "Another perspective on the coca-cola affair in postwar France". Enterprise and Society 18.1 (2017): 108-145.

14. Pedro Luiz MR., et al. "Protective effect of grape or apple juices in bone tissue of rats exposed to cadmium: Role of RUNX-2 and RANK/L expression". Environmental Science and Pollution Research International 25.16 (2018): 15785-15792.

15. Rinzler CA. 5th Edition. Nutrition for Dummies. Wiley Publishing.

16. Rogers E. Shift your habit. Three Rivers Press, New York, NY (2010).

17. Rogers EJ., et al. "Apple juice prevents oxidative stress and impaired cognitive performance caused by genetic and dietary deficiencies in mice". Journal of Nutritional Health Aging 8.2 (2004): 92-97.

18. Seventy - Ninety \% of Indians are vitamin D deficient and at risk of having diabetes and hypertension BipSpectrum (2019).

19. Shao-Wen S. "Tea or coffee: A study of the beverage choice pattern and its affecting factors at teatime in kaohsiung, Taiwan". Asia Pacific Management Review 12.4 (2007). 
20. Silcox S. "Why hydration is a workplace issue". Occupational Health 67.9 (2015): 12-13.

21. The Merck Manual Home Health Handbook. Merck and Co. Inc, Whitehouse Station, NJ. Turmeric Latte, Golden milk Chef in disguise.

22. Wong YL and Volken DL. "Caring for students with type 1 diabetes: school nurses experiences". Journal of School Nursing 1 (2013): 31-38.

\section{Assets from publication with us}

- Prompt Acknowledgement after receiving the article

- Thorough Double blinded peer review

- Rapid Publication

- Issue of Publication Certificate

- High visibility of your Published work

Website: www.actascientific.com/

Submit Article: www.actascientific.com/submission.php

Email us: editor@actascientific.com

Contact us: +919182824667 